\title{
Software Maintenance Problem Identified
}

National Cancer Institute

\section{Source}

National Cancer Institute. Software Maintenance Problem Identified. NCI Thesaurus.

Code C139516.

The device software was not maintained/updated properly. 